\title{
KONTRIBUSI DUKUNGAN TEMAN SEBAYA TERHADAP REGULASI DIRI PADA REMAJA
}

\author{
Munawarah, Latipun, Sofa Amalia \\ Universitas Muhammadiyah Malang \\ muna.warah376@gmail.com, lativ_un1@yahoo.com,sofamalia@umm.ac.id
}

\begin{abstract}
Abstrak: Regulasi diri membuat remaja dapat terhindar dari perilaku yang tidak sehat, seperti perilaku membolos, pengaruh negatif dari lingkungan dan penggunaan zat terlarang. Memiliki tujuan hidup yang akan dicapai akan membuat remaja mengatur dirinya dengan baik. Tujuan penelitian adalah untuk mengetahui kontribusi dukungan teman sebaya terhadap regulasi diri pada remaja. Metode pengambilan data pada penelitian ini menggunakan simple random sampling. Peneliti menyebarkan skala di empat sekolah menengah pertama yang ada di Malang dengan jumlah subjek 347 orang. Hasil regresi linier menunjukkan bahwa dukungan teman sebaya berpengaruh secara signifikan terhadap regulasi diri dengan nilai signifikan sebesar $\mathrm{p}=0.00$. adapun besar nilai koefisien regresi $(\mathrm{F}=34.10 ; \mathrm{r}=0.30 ; \mathrm{R} 2=0.09)$ yang mengartikan bahwa terdapat pengaruh positif yang signifikan antara dukungan teman sebaya terhadap regulasi diri. Semakin tinggi dukungan teman sebaya maka semakin tinggi pula regulasi diri pada remaja.
\end{abstract}

Kata Kunci: Dukungan Teman Sebaya, Regulasi Diri

Abstract: Regulations make teenagers can avoid unhealthy behavior, such as the habit of ditching, negative influences from the environment and the use of prohibited substances. Having life goals that will be achieved will make teenagers agree well. The aim of the study was to study peer approval for self-approval in adolescents. The data collection method in this study used simple random sampling. The researcher changed the scale in junior high schools in Malang with a total subject of 347 people. The linear regression results that showed peer support were agreed to be significant to self-regulation with a significant value of $p=0.00$. as for the large regression coefficient $(F=34.10 ; r=0.30 ; R 2=0.09)$ which means that there is a significant positive effect between peer support for self-regulation. The higher the peer support, the higher self-approval in adolescents will be.

Keywords: Peer Support, Self Regulation

\section{PENDAHULUAN}

Regulasi diri membantu individu untuk menggapai tujuan dalam hidupnya, semakin besar usaha untuk menggapai tujuan akan semakin baik individu dalam me-regulasi diri. Beberapa aspek yang mendasari munculnya regulasi diri, yaitu: individu mampu untuk merancang suatu tindakan yang akan dilakukan kedepannya, munculnya motivasi yang berasal dari lingkungan maupun dalam diri individu dan melakukan tindakan positif sesuai dengan tujuan hidupnya yang dapat diterima oleh lingkungan sekitar (Manab, 2016). Menurut Vago dan Silbersweig (2012), regulasi diri merupakan sebuah kemampuan yang berasal dari dalam diri untuk mendorong seseorang mencapai suatu tujuan. Seuai dengan penelitian sebelumnya yang dilakukan oleh Istriyanti dan Simarmata (2014), terdapat hubungan positif antara regulasi diri dengan perencanaan karir pada remaja, hasil menunjukkan semakin tinggi regulasi diri pada remaja maka akan 
semakin tinggi pula perencanan karir yang dimiliki.

Masa remaja dihadapkan pada situasi yang mengharuskannya untuk mengambil keputusan dan menentukan tujuan hidup, seperti pertemanan, percintaan, memilih jurusan perkuliahan, dan apa yang ingin mereka lakukan di masa depan. Remaja akan berjuang untuk mengejar dan menggapai tujuan yang sudah mereka tentukan. Regulasi diri yang baik akan membantu remaja untuk mengatur dirinya dan mengambil keputusan untuk tujuan yang ingin diraih. Aziroh (2017), menjelaskan bahwa regulasi diri pada remaja dipengaruhi oleh keinginan untuk mendapatkan prestasi di sekolah, artinya regulasi diri remaja akan baik ketika remaja memiliki motivasi yang dapat membantu dalam menggapai suatu tujuan.

Regulasi diri dimiliki oleh setiap individu akan tetapi belum tentu individu tersebut mampu memanfaatnya dengan baik, oleh karena itu remaja harus berlatih untuk mengembangkan regulasi diri sehingga dapat menentukan pilihan-pilihan hidup dan menemukan gambaran masa depannya. Dalam proses menggapai tujuan kedepan diperlukan regulasi diri yang baik karena akan ada kesulitan dan kelelahan akibat terlalu keras perjuangan untuk menggapai suatu tujuan, seperti rasa tidak suka, malas, ingin bersenang-senang, ingin menyerah, rasa terbebani, lelah, takut kalah, dan berkecil hati. Membentuk regulasi diri yang baik tentunya memiliki regulasi emosi yang baik agar tekanan-tekanan dalam mencapai suatu tujuan mampu diatasi dengan baik.

Masa remaja awal merupakan masa pertumbuhan dan perubahan yang pesat, perubahan- perubahan yang pesat menimbulkan dampak pada anak. Misalnya timbul keraguan, perasaan tidak mampu dan tidak aman dan dalam beberapa hal memungkinkan timblnya perilaku negatif (Kurniasih, 2011). Remaja yang memiliki kemampuan untuk mengatur dirinya atau me-regulasi dirinya dengan baik, akan merencanakan masa depannya dengan baik pula. Remaja yang dapat me-regulasi dirinya akan terhindar dari perilaku yang tidak sehat, seperti perilaku membolos, pengaruh negatif dari lingkungan dan penggunaan zat terlarang, dikarenakan ketika remaja mampu untuk meregulasi dirinya, remaja akan menghabiskan waktunya untuk menggapai suatu tujuannya. Menurut Bandy dan Moore (2010), remaja perlu mengembangkan keterampilan regulasi diri karena terdapat pengaruh kuat dari regulasi diri terhadap kesiapan sekolah dan membangun hubungan dengan teman sebaya.

Kehidupan sosial berperan penting dalam pengambilan keputusan remaja. Penelitian sebelumnya yang dilakukan oleh Nuperawati, Yufiarti, dan Sumantri (2018) menyatakan terdapat hubungan positif antara regulasi diri dengan keterampilan sosial pada remaja, hasil penelitian menunjukkan bahwa semakin tinggi regulasi diri maka semakin tinggi pula keterampilan sosial pada remaja. dari lingkungan sosial, remaja bekerja untuk meregulasi dirinya dengan cara mengendalikan impuls dan mengevaluasi diri, saat remaja memiliki kemampuan regulasi diri yang baik ia akan memiliki keterampilan sosial yang baik pula, dengan mengerti dan memahami perasaan orang lain remaja akan menciptakan suatu hubungan atau relasi positif dengan orang lain. Menurut Nuperawati et al., (2018) regulasi diri sangat penting terhadap keterampilan sosial remaja. Tolok ukur keterampilan sosial seseorang dikatakan baik ketika seseorang mampu untuk meregulasi dirinya, saat lingkungan sekitar memberikan dorongan yang positif ia akan mampu mencapai tujuannya.

Menurut Aziroh, (2017), terdapat faktor eksternal yang membentuk regulasi diri. adapun faktor eksternal, yaitu: (1) lingkungan berkaitan dengan pengaruh pribadi, membentuk standar evaluasi diri seseorang. Melalui lingkungan (teman, 
orangtua maupun guru) seseorang belajar baik dan buruk, tingkah laku yang dikehendaki maupun yang tidak dikehendaki; (2) Penguatan, ketika orang dapat mencapai standar tingkah laku tertentu perlu penguatan agar tingkah laku tersebut menjadi pilihan dan dilakukan lagi. Remaja lebih banyak menghabiskan waktunya dengan teman sebaya. Persepsi lingkungan dan penguat didapatkan remaja melalui dukungan teman sebaya seperti dukungan emosional, dukungan penghargaan, dan juga dukungan informasi. Ketika remaja mendapatkan suatu dukungan dari teman sebaya, regulasi diri pada remaja akan terbentuk dengan sendirinya.

Menurut Santrock (2012), pengambilan keputusan akan meningkat ketika mendapatkan motivasi dari kehadiran teman sebaya. Hal ini dikarenakan remaja lebih banyak menghabiskan waktu dengan lingkungan pertemanan. Bagi remaja berkumpul dengan teman-teman sangatlah mengesankan, seperti penelitian sebelumnya yang dilakukan oleh Taa dan Sawitri (2017), bahwa terdapat hubungan positif antara dukungan teman sebaya dengan efikasi diri akademik pada siswa SMA/SMK beretnis Papua di Semarang, hasil menunjukkan bahwa semakin tinggi dukungan teman sebaya maka semakin tinggi pula efikasi diri akademik pada siswa. Menurut Saputri dan Indrawati (2011) dukungan sosial merupakan bantuan yang didapat individu dari orang lain atau kelompok, baik berupa bantuan materi maupun non materi, yang dapat menimbulkan perasaan nyaman secara fisik dan psikologis bagi individu yang bersangkutan. Salah satu sumber dukungan sosial pada remaja adalah teman sebaya yang mencakup sahabat karib, teman sebangku di sekolah maupun teman seperkumpulan.

Menurut Ristianti (2008) dukungan sosial merupakan salah satu hal penting untuk terbentuknya identitas diri seorang remaja. Dorongan lingkungan kepada remaja mampu membuat remaja untuk lebih bersemangat dalam melakukan aktivitasnya. Dorongan yang diberikan dari lingkungan sosial kepada remaja membuatnya tidak mudah ragu, dikarenakan adanya dukungan berupa semangat, saran maupun kritik yang membangun. Seperti yang dikemukakan oleh Elleny (2007), bahwa dukungan sosial yang bersumber dari kelompok teman sebaya dapat membantu remaja mengatasi krisis dalam upaya pencapaian identitas.

Peran lingkungan sosial tidak bisa dipisahkan dari perkembangan remaja. Menurut Brown dan Prinstein (2011) remaja banyak menghabiskan waktunya dua sampai tiga kali lipat bersama dengan teman sebaya dibandingkan dengan orang tua atau orang dewasa lainnya, membuat remaja lebih bergantung kepada teman sebayanya dibandingkan orang tua atau saudaranya. Teman sebaya akan terlibat dalam interaksi keseharian remaja, rasa senang dan sedih akan dibagi sebagai bentuk rasa akrab antara remaja dengan teman sebayanya. Hubungan akrab yang terjalin dengan teman sebaya akan menimbulkan suatu dukungan ketika remaja mengalami masa-masa sulit. Penelitian yang dilakukan oleh Lutfi (2012) salah satu dukungan sosial yang diterima santiwati di pondok pesantren adalah dukungan yang berasal dari teman-teman terdekatnya dimana dukungan sosial dan optimisme merupakan sala satu hal yang penting pada masa remaja, dimana pada masa transisi tersebut sangat membutuhkan dukungan dan pola berfikir positif untuk mengambil keputusan-keputusan dalam memecahkan masalah dalam menghadapi tekanan dan permasalahan dalam kehiduan nyata.

Menurut Leme, Del Prette, dan Coimbra (2015), dukungan sosial merupakan mekanisme perlindungan eksternal yang penting terhadap kemungkinan hambatan yang dapat digunakan seseorang untuk menghadapi perubahan di dalam dan di luar lingkungan 
keluarga. Smith et al., (2011), dukungan teman sebaya adalah dorongan yang didapatkan individu berdasarkan pada pengalaman hidup yang serupa. Beberapa pengertian diatas dapat disimpulkan bahwa dukungan teman sebaya merupakan pertolongan dari individu berupa semangat atau dukungan, saran, penerimaan dan perhatian yang didasari oleh pengalaman yang serupa.

Remaja dan teman sebayanya memiliki pengalaman hidup dan menghabiskan waktu bersama, mereka akan saling berkomunikasi ataupun bertukar pikiran bersama, oleh karena itu dukungan teman sebaya sangat penting untuk perkembangan remaja. Seperti penelitian sebelumnya yang dilakukan oleh Ulfah dan Ariati (2017), terdapat hubungan positif dan signifikan antara dukungan teman sebaya dengan motivasi berprestasi pada remaja. Hasil menunjukkan semakin positif dukungan teman sebaya maka akan semakin tinggi motivasi berprestasi siswa. Sebaliknya, semakin negatif dukungan teman sebaya maka akan semakin rendah motivasi berprestasi siswa.

Menurut Ulfah dan Ariati (2017), teman sebaya menjadi faktor eksternal yang dapat mendukung individu untuk memunculkan dorongan dalam mencapai tujuan. Menurut Zimmerman (2000) regulasi diri memiliki dimensi sosial, jika seseorang mengabaikan lingkungan sosial atau memandang lingkungan sosial sebagai penghambat, maka regulasi dirinya tidak akan efektif. Ketika ada hal yang buruk terjadi pada lingkungan sosialnya dan hal tersebut dapat menghambat dalam menggapai tujuannya, ia akan mencoba untuk mengevaluasi hal tersebut apakah baik atau tidak dalam dirinya.

Dari beberapa penelitian sebelumnya mengenai dukungan teman sebaya dan regulasi diri maka penulis ingin mengetahui bagaimana kontribusi dukungan teman sebaya terhadap regulasi diri pada remaja. Salah satu faktor seseorang dapat meregulasi dirinya yaitu faktor eksternal yang terdiri dari pengaruh lingkungan dan penguatan (reinforcement). Dari beberapa literatur peneliti banyak yang meneliti faktor internal dan jarang meneliti faktor eksternal. Maka dari itu peneliti ingin meneliti apakah dukungan teman sebaya mampu berperan pada remaja dalam melakukan regulasi diri. Hal ini karena mempertimbangkan pentingnya peran teman sebaya pada tahap perkembangan remaja yang merupakan partisipan penelitian.

Urgensi penelitian ini untuk mencari apakah ada pengaruh dan seberapa besar kontribusi dukungan teman sebaya terhadap regulasi diri pada remaja. Secara keilmuan, penelitian ini diharapkan memberi kontribusi ilmiah pada kajian mengenai psikologi pendidikan. Kajian mengenai psikologi pendidikan sudah banyak yang membahas tentang regulasi diri, namun sedikit riset yang secara spesifik fokus membahas mengenai faktor eksternal dari regulasi diri. Oleh karena itu, riset ini diharapkan mampu menyediakan referensi baru baru tentang faktor eksternal yang mempengaruhi regulasi diri. Manfaat praktis pada penelitian tersebut, yaitu: (1) hasil dari penelitian ini dapat memberikan masukan bagi pihak sekolah maupun keluarga mengenai ada tidaknya pengaruh dukungan teman sebaya terhadap regulasi diri, sehingga dapat menjadi bahan pertimbangan untuk mengatasi masalah yang berkaitan dengan Regulasi diri; (2) sebagai bahan untuk mengatasi masalah yang berkaitan dengan Regulasi diri pada remaja.

Menurut Istriyanti dan Simarmata (2014), Regulasi diri adalah kemampuan untuk mengontrol perilaku sendiri dan salah satu dari sekian penggerak utama kepribadian manusia yang terdiri dari pengamatan, penilaian dan respon diri. Menurut Bandy dan Moore (2010) regulasi diri merupakan keterampilan yang memiliki pengaruh penuh pada kemampuan individu 
untuk mentoleransi keinginan atau kebutuhan yang belum terpenuhi, menangani kekecewaan dan kegagalan, dan bekerja menuju kesuksesan. Regulasi diri adalah kemampuan individu dalam memotivasi diri untuk mencapai tujuan dengan cara merencanakan, mengevaluasi dan memodifikasi perilaku individu sendiri Yayan, Yuniarrahmah, dan Anward (2016). Dari beberapa pengertian tersebut dapat disimpulkan regulasi diri merupakan kemampuan dari diri seseorang dalam mengatur hidupnya sendiri dari kemauan seseorang untuk mencapai suatu tujuan sehingga ia mampu untuk mengevaluasi diri dengan berusaha menghindari gangguan lingkungan dan rangsangan emosional yang dapat mengganggu dalam menggapai target atau tujuan hidup.

Menurut Santrock (2012), salah satu perkembangan sosioemosi remaja ialah tahap pembentukan identitas. Pencarian identitas pada usia remaja mengenai siapa mereka selama ini, siapa mereka sekarang dan akan menjadi apa mereka dimasa mendatang. Tujuan yang ditetapkan pada masa remaja akan mempengaruhi perilaku dalam menggapainya. Mampu meregulasi diri dengan baik ditandai dengan adanya faktor lingkungan yang berfungsi untuk membantu seseorang dalam mengevaluasi diri. Bukan hanya itu, adanya penguat seperti saran dan juga dukungan dari lingkungan sekitar membuat seseorang dapat meregulasi diri dengan baik. regulasi diri yang baik tidak terlepas dari faktor eksternal remaja atau hubungan sosial remaja, orang terdekat mampu untuk membuat remaja melakukan regulasi diri.

Remaja yang mampu merencanakan sebelum mengerjakan sesuatu diimbangi dengan keyakinan maka akan dapat meningkatkan ketekunan dan akan menghasilkan prestasi akademik. Menurut Bandy dan Moore (2010) hasil dari regulasi diri pada remaja: (1) Prestasi akademik. (2) Disiplin. (3) Penerimaan lingkungan. (4) Terhindar dari perilaku negatif. (5) Pola hidup yang sehat, remaja yang me-regulasi diri akan mampu mengatur perilaku mereka dengan kebiasaan-kebiasaan hidup yang sehat.

Menurut Walen dan Lachman (2000), dukungan sosial merupakan kepedulian individu kepada individu lainnya berupa dorongan maupun saran. Menurut Smith et al., (2011), dukungan teman sebaya telah didefinisikan sebagai penyediaan dukungan dari individu dengan pengetahuan pengalaman berdasarkan pada berbagai pengalaman hidup serupa. Dari pengertian diatas dapat disimpulkan dukungan teman sebaya merupakan pertolongan/keberadaan individu berupa semangat, saran dan perhatian yang didasari oleh pengetahuan pengalaman berdasarkan berbagai pengalaman hidup yang serupa dengan individu lainnya.

Remaja lebih banyak menghabiskan waktunya dengan teman-teman disekolah seperti teman sebayanya. Dukungan dari teman sebaya didapatkan melalui pengalaman hidup yang sama antara individu satu dengan individu lainnya, salah satunya disekolah. Dukungan yang diperoleh individu dari sahabat karib meningkatkan motivasi akademik individu. Teman sebaya sangat penting dalam memberikan dukungan sosial, bukan hanya karena mengabiskan waktu bersama, teman sebaya juga memiliki pemikiran yang sejalan dikarenakan pengalaman yang sama. Ketika mendapatkan dukungan dari teman sebaya remaja menjadi termotivasi. Saran yang diberikan sesuai dengan apa yang dirasakan individu karena remaja mampu bercerita dengan nyaman bersama teman sebaya yang memiliki pengalaman yang sama.

Teori Kognitif Sosial menyatakan bahwa perilaku, lingkungan dan kognisi merupakan faktor- faktor penting dalam perkembangan. Bandura menegaskan bahwa proses-proses kognitif memiliki kaitan penting dengan lingkungan dan perilaku. Program penelitian awal yang 
dilakukannya terutama berfokus pada pembelajaran melalui observasi atau observational learning (disebut juga imitation atau modeling), yaitu pembelajaran dengan menggunakan observasi terhadap hal-hal yang dilakukan orang lain (Santrock, 2012). Belajar dapat siswa dapatkan dari mana saja, akan tetapi pembelajaran siswa melibatkan tiga aspek, yaitu; perilaku, pribadi/kognitif dan lingkungan. Kognitif/pribadi berupa pemikiran dan perencanaan, dimana ketika kita mampu untuk membuat perencanaan dalam hidup dan akhirnya mampu untuk meyakini diri sendiri bahwa ia dapat mengendalikan keberhasilannya. Perilaku berupa menerapkan apa yang sudah dipelajari melalui observasi. Sedangkan lingkungan berupa objek yang merupakan bentuk observasi yang dilakukan oleh individu.

Manusia dan lingkungannya saling mempengaruhi, para pembelajar mempengaruhi lingkungan, seringkali secara sadar dan sengaja. Dalam tingkah tertentu, pembelajar mempengaruhi lingkungannya melalui perilaku mereka (Ormrod, 2008). Keputusan siswa dalam memilih aktivitas ektrakurikuler ataupun teman dekat sangat menentukan bagaimana siswa belajar melalui lingkungannya. Tidak lupa juga proses kognitif internal maupun karakteristik kepribadian individu sangat mempengaruhi. Ketika siswa belajar melalui lingkungan, peran internal individu sangat penting untuk membantu menentukan keputusan. Maka dari itu proses kognitif/pribadi dan lingkungan sangat terikat satu sama lain yang akhirnya akan menimbulkan sebuah perilaku atau juga bisa disebut keputusan dalam hidup individu.

Teori Sosial Kognitif memiliki kesamaan dalam penekanan akan pentingnya kepercayaan, persepsi dan observasi perilaku orang lain dalam menentukan apa yang kita pelajari dan bagaimana kita bertindak (Wade \& Travis,
2007). Peran lingkungan disini ialah berupa keberadaan dari orang terdekat, yaitu (1) kepercayaan yang diberikan kepada orangorang terdekat kepada individu berupa dorongan dan keyakinan bahwa individu mampu untuk melakukan suatu hal yang ia inginkan. (2) Persepsi, pendapat maupun saran yang diberikan oleh orang terdekat kepada individu diharapkan mampu untuk menjadi bahan evalusi individu untuk melakukan sesuatu. (3) Observasi, proses dimana individu mengamati apa yang ada di lingkungannya dan juga menjadi proses belajar dari individu.

Lingkungan individu sangat berperan dengan adanya dukungan, keyakinan, dan persepsi dari orang terdekat. Salah satu orang terdekat yang selalu bersama dengan remaja ialah teman sebaya, dikarenakan intensitas pertemuan yang sangat sering. Menurut Smith et al., (2011) dukungan teman sebaya telah didefinisikan sebagai penyediaan dukungan dari individu dengan pengetahuan pengalaman berdasarkan pada berbagai pengalaman hidup serupa. Penyediaan dukungan dari teman sebaya tersebut berupa dukungan emosional, penghargaan dan informasi. Dukungan tersebut mampu untuk mempengaruhi pemikiran seseorang, dengan memberikan saran, dukungan, informasi dan penghargaan atas apa yang dilakukan akan menjadikan dukungan tersebut menjadi suatu penguat bagi individu untuk melakukan sesuatu atau membuat suatu keputusan dalam hidupnya.

Dari dukungan tersebut remaja akan melakukan pembelajaran melalui observasi, dari observasi pada lingkungannya mempengaruhi individu pada kognitifnya. Karena selain lingkungan seseorang, proses kognitif internal maupun karakteristik kepribadian dari individu sangat mempengaruhi. Dukungan yang diterima akan sampai pada kognitif individu sebagai sumber informasi dalam menetapkan tujuannya, setelah itu dengan tujuan yang sudah ditetapkan akan mempengaruhi 
perilaku individu. Seperti termotivasi untuk berubah dengan memantau kemajuan yang dilakukannya untuk mencapai suatu tujuan dengan konsisten. Perilaku yang ditunjukkan ialah bekerja sesuai dengan rencana, setelah bekerja sesuai dengan rencana, individu akan melakukan evaluasi pada apa yang sudah dikerjakannya.

Peneliti memberikan hipotesis bahwa terdapat pengaruh dukungan teman sebaya terhadap regulasi diri pada remaja.

\section{METODE}

Metode dalam penelitian ini adalah pendekatan kuantitatif yakni metode penelitian yang digunakan untuk meneliti pada populasi atau sampel tertentu, pengumpulan data menggunakan instrumen penelitiaan, analisis data bersifat statistik, dengan tujuan untuk menguji hipotesis yang telah ditetapkan. Penelitian ini menggunakan desain penelitian kausal yang artinya penelitian yang ingin melihat penyebab dari suatu variabel tertentu, halhal apa saja yang mempengaruhi suatu variabel. Penelitian ini berbentuk penelitian cross sectional dimana data penelitian didapatkan dalam waktu sekaligus.

Subjek yang akan dipilih adalah remaja SMP yang ada di Malang dengan jumlah 347 orang. Penelitian ini dilakukan secara acak disebar secara langsung pada kriteria remaja, rentang usia 12 sampai dengan 18 tahun dengan jenis kelamin lakilaki maupun perempuan. Metode pengambilan data pada penelitian ini menggunakan simple random sampling. Simple random sampling adalah metode dengan mengambil anggota sample dari populasi dilakukan secara acak tanpa mempeerhatikan strata yang ada dalam populasi tersebut. Peneliti memilih remaja dengan rentan usia 12 sampai 15 tahun mulai kelas VII, VIII, dan IX. Subjek dalam penelitian ini adalah siswa SMP Negri yang ada di Kota Malang dengan usia 12 sampai 15 tahun berjenis kelamin laki-laki dan perempuan. Total subjek dalam penelitian ini adalah 347 siswa dengan kriteria diatas. Pada tabel 1, dijelaskan tentang data demografis suku, kelas dan status keluarga:

Tabel 1.

Deskripsi Subjek Penelitian

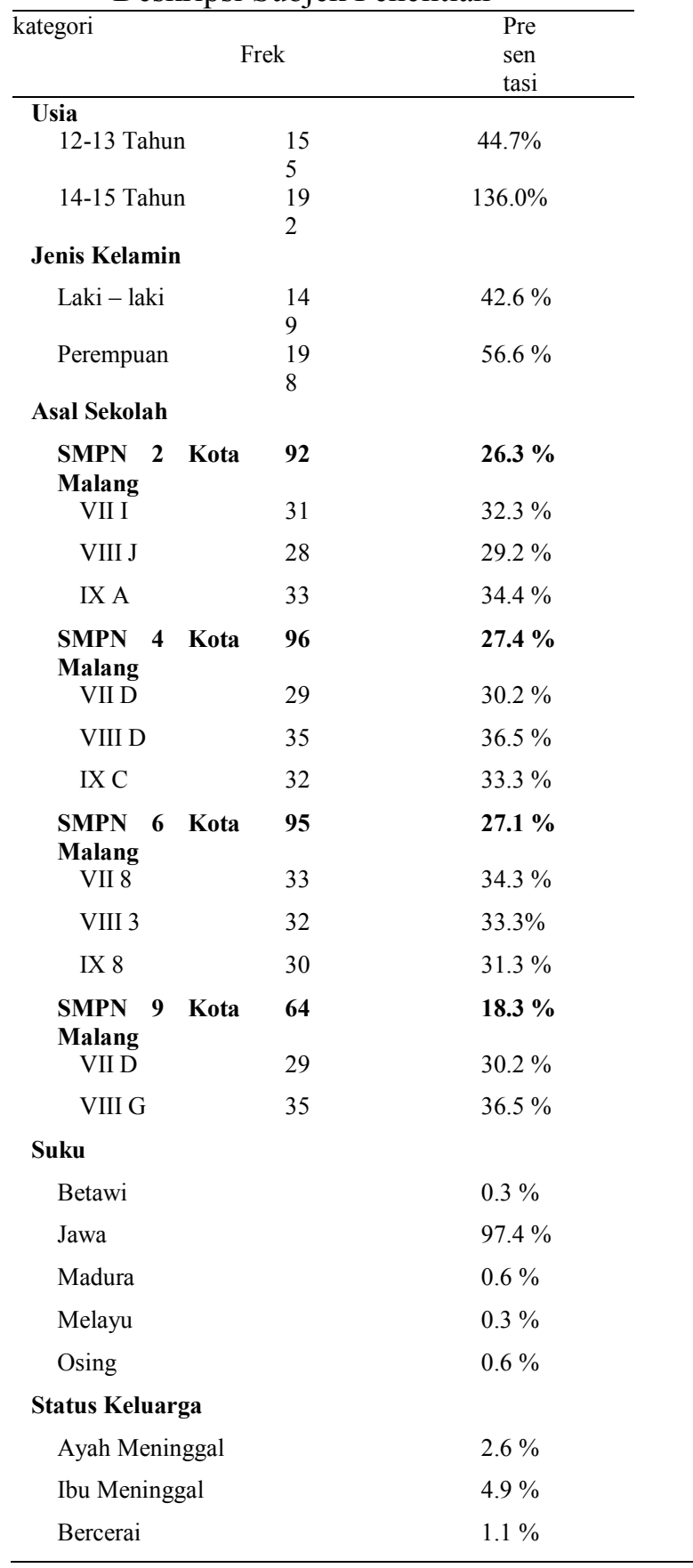

Regulasi diri adalah kemampuan mengatur diri pada remaja untuk menggapai suatu tujuan yang diukur melalui the Spanish version of the Self-Regulation (SRQ). The Spanish version of th The Self 
Regulation (SRQ) dikembangkan oleh Carmen Pichardo, Fernando Justicia, Jesus de la Fuente, Jose Manuel Martinz-Vicente \& AnaB. G. Berben (2014), digunakan untuk mengukur regulasi diri. Skala tersebut turunan dari The Self Regulation yang dikembangkan oleh Brown Miller \& Lawendowski (1999) menghasilkan 17 item untuk mewakili empat sub skala yaitu: goal setting (penetapan tujuan), perseverance (ketekunan), decision making (pengambilan keputsan) \& learning from mistake (belajar dari kesalahan). Skala tersebut menggunakan skala likert dengan lima pilihan jawaban yakni sangat tidak setuju, tidak setuju, rata-rata, setuju dan sangat setuju. Pemberian skor tergantung pada favorabel dengan skor 5 (Sangat setuju) sampai 1 (Sangat tidak setuju) sedangkan unvaforabel dengan skor 1 (Sangat setuju) sampai 5 (Sangat tidak setuju). Salah satu contoh item yang ada pada skala The Spanish version of th The Self Regulation (SRQ), yaitu : Saya menetapkan tujuan untuk diri saya sendiri dan mencatat kemajuan saya. Dalam penelitian ini didapatkan nilai konsistensi internal $\alpha=0.72$. Dukungan teman sebaya adalah penilaian remaja tentang dorongan atau pertolongan dari teman sebaya berupa semangat, saran, penerimaan dan perhatian yang didasari oleh berbagai pengalaman hidup lainnya yang diukur melalui Peer Support Evaluation Inventory (PSEI). Peer Support Evaluation Inventory (PSEI) yang dikembangkan oleh Cindy-Lee Dennis (2003). Skala terdiri dari 28 item mewakili empat sub skala yaitu: supportive interactions (interaksi yang mendukung), relationship qualities (kualitas hubungan), perceived benefits (keuntungan yang didapat) \& satisfaction (kepuasan). Berbentuk Skala Likert dengan lima pilihan jawaban, yaitu sangat tidak setuju, tidak setuju, rata-rata, setuju, sangat setuju. Pemberian skor tergantung pada favorabel dengan skor 5 (Sangat setuju) sampai 1 (Sangat tidak setuju) sedangkan unvaforabel dengan skor 1 (Sangat setuju) sampai 5 (Sangat tidak setuju). Salah satu contoh item yang ada pada skala Peer Support Evaluation Inventory (PSEI), yaitu : Teman saya menemani saya dalam menemukan pemecahan masalah yang saya hadapi. Dalam penelitian ini didapatkan nilai konsistensi internal $\alpha=0.90$.

Penelitian yang akan dilakukan memiliki tiga prosedur utama sebagai berikut: Tahap pertama ialah tahap persiapan dimana peneliti menentukan tema yang akan dibahas dan setelah menentukan tema yang akan dibahas peneliti akan mendalami materi tersebut. Setelah itu peneliti mengembangkan alat ukur berdasarkan variabel yang sudah ditentukan, dengan melakukan validitas isi (Content Validity). Validitas isi dilakukan oleh orang-orang yang memiliki keahlian yang bekaitan dengan variabel yang akan diteliti atau dapat disebut dengan expert judgement. Expert judgement yang dilakukan untuk melalukan validitasi isi pada skala apakah item dapat dimengerti pada usia remaja atau tidak.

Setelah itu peneliti mengurus perijinan untuk melakukan penelitian (pengambilan data). Setelah mendapatkan ijin dari sekolah, peneliti melakukan uji coba try out sengan subjek try out 50 subjek di satu sekolah dengan karakteristik remaja dengan usia 12 sampai 15 tahun. Selanjutnya peneliti melakukan analisa data menggunakan Statistical Package For Social Sciense (SPSS) 21 untuk mendapatkan item valid dan reliabel.

Pelaksanaan, pada tahap ini peneliti mulai menyebarkan skala sesui dengan jumlah populasi yang sudah didapatkan sebelumnya. Jika try out peneliti hanya menggunakan satu sekolah saja, pada tahap pelaksanaan peneliti menggunakan empat sekolah yang sudah diurus perijinannya terlebih dahulu. Dari empat sekolah tersebut peneliti mendapatkan 347 subjek dengan rentan usia 12 - 15 tahun. Jadi semua kuisioner yang disebar sebanyak 347 
kuisioner digunakan dan diolah karena sudah sesuai dengan karakteristik peneliti.

\section{HASIL}

Tabel 2.

Mean dan Standar Deviasi Variabel $(\mathrm{N}=347)$

\begin{tabular}{lrl}
\hline Variabel & Mean & SD \\
\hline Dukungan & Teman108.26 & 12. \\
Sebaya & & 12 \\
Regulasi Diri & 63.54 & 7.8 \\
& & 3 \\
\hline
\end{tabular}

Tabel 2 menunjukkan hasil uji statistik nilai rata-rata variabel dukungan teman sebaya $(\mathrm{M}=108.26$ dan $\mathrm{SD}=12.12)$. Pada variabel regulasi diri $(\mathrm{M}=63.54$ dan $\mathrm{SD}=7.83$ ). Berdasarkan uji Kolmogorov smirnov menunjukkan sebaran data pada skala dukungan teman sebaya sebesar 0.051 $>0.05$. Sedangkan pada skala regulasi diri sebesar $0.27>0.05$. Jadi, dapat disimpulkan bahwa data yang diperoleh dari penelitian memiliki distribusi normal. Berdasarkan hasil regresi dapat disimpulkan bahwa dukungan teman sebaya berpengaruh yang signifikan terhadap regulasi diri dengan nilai signifikan sebesar $\mathrm{p}=0.000$. Adapun besar nilai koefisien regresi $(\mathrm{r}=0.300$; $\mathrm{R} 2=$ 0.090) yang mengartikan bahwa kontribusi yang diberikan dukungan teman sebaya terhadap regulasi diri sebesar $9 \%$ dan terdapat pengaruh positif yang signifikan antara dukungan teman sebaya terhadap regulasi diri. Hal ini berarti semakin positif dukungan teman sebaya maka semakin tinggi pula regulasi diri pada remaja. Sebaliknya, semakin negatif dukungan teman sebaya maka semakin rendah pula regulasi diri pada remaja.

Berdasarkan uji korelasi pada tabel 3. antara dimensi dukungan teman sebaya terhadap regulasi diri diperoleh bahwa nilai koefisien korelasi dimensi peran dalam variabel dukungan teman sebaya terhadap regulasi diri yaitu sebesar 0.30. Nilai koefisien korelasi dimensi kualitas hubungan lebih

besar daripada dimensi lain dalam dukungan teman sebaya seperti interaksi yang mendukung $(\mathrm{r}=0.29, \quad \mathrm{p}=0.00)$, keuntungan yang didapatkan $(\mathrm{r}=0.22$, $\mathrm{p}=0.00)$ dan kepuasan $(\mathrm{r}=0.16, \mathrm{p}=0.00)$.

Tabel 3

\begin{tabular}{lllllll}
\multicolumn{6}{c}{ Uji Korelasi dan Regresi Aspek } \\
\hline $\begin{array}{l}\text { Vari } \\
\text { abel }\end{array}$ & $\begin{array}{l}\text { Regu } \\
\text { lasi } \\
\text { Diri }\end{array}$ & $\mathrm{R}^{2}$ & $\mathrm{p}$ & $\mathrm{F}$ & Mean & SD \\
\hline $\begin{array}{l}\text { Dukun } \\
\text { gan }\end{array}$ & 0.30 & 0.0 & 0.00 & 34.10 & & \\
$\begin{array}{l}\text { Teman } \\
\text { Sebaya }\end{array}$ & & 9 & & & & \\
$\begin{array}{l}\text { Interak } \\
\text { si yang } \\
\text { diduku }\end{array}$ & 0.29 & & 0.00 & 50 & 2.98 \\
ng & & & & & & \\
$\begin{array}{l}\text { Kualitas } \\
\text { hubungan }\end{array}$ & 0.30 & 0.00 & 42 & 5.00 \\
$\begin{array}{l}\text { Keuntung } \\
\text { an }\end{array}$ & 0.22 & & 0.00 & 32 & 2.84 \\
didapatka & & & & & \\
$\mathrm{n}$ & & & & & \\
Kepuasan & 0.16 & 0.00 & 22 & 2.11 \\
\hline
\end{tabular}

\section{PEMBAHASAN}

Hasil peneltian Wills dan Bantum (2012) dimana peneliti menyebutkan bahwa dukungan sosial akan membuat individu mampu untuk mengatur dirinya dalam keadaan tertekan. Hal ini terjadi dikarenakan dukungan yang didapatkan berupa dukungan emosional, dukungan penghargaan dan dukungan informasi yang menjadikan remaja memiliki seseorang dengan pengalaman yang sama. Menurut Wills dan Bantum (2012) pada kalangan remaja, sumber dukungan itu sangatlah penting yang membuat individu terbebas dari keadaan tertekan dan membuat individu mengatur dirinya dengan baik. Hal ini sesuai dengan faktor yang mempengaruhi seseorang dalam regulasi diri, yaitu adanya penguat dari lingkungan agar seseorang dapat menentukkan tujuan hidupnya dengan baik (Aziroh, 2017).

Dukungan yang didapatkan oleh remaja tidak hanya dari teman sebaya saja akan tetapi remaja juga mendapatkan dukungan yang penuh dari keluarga 
terdekatnya. Seperti pendapat Wills dan Bantum (2012), sumber dukungan yang didapatkan oleh remaja dari mana saja, akan tetapi dukungan dari orang tua sangat berpengaruh besar bagi remaja. Dukungan sosial merupakan suatu kebersamaan sosial dimana individu berada di dalamnya, yang memberikan beberapa dukungan seperti bantuan nyata, dukungan informasi, dan dukungan emosional sehingga individu merasa nyaman (Almasitoh, 2011). Seperti penelitian yang dilakukan oleh Pardede, Supena, dan Fahrurrozi (2018) bahwa regulasi diri dan kelekatan orang tua memiliki hubungan yang positif pula. Dukungan teman sebaya maupun kelekatan orang tua akan menghasilkan regulasi diri pada remaja, membuat remaja dapat menetapkan tujuan hidupnya kedepannya dengan membuat dan melakukan hal-hal yang dapat mencapai tujuannya tersebut. Kualitas hubungan teman sebaya adalah salah satu aspek penting dari lingkungan sosial remaja Oppenheimer dan Hankin (2011). Karena dari kualitas hubungan itulah dapat melihat bagaimana seseorang memberikan kenyamanan psikologis dengan cara membuat kondisi agar seseorang menjadi bagian dari suatu kelompok sosial seperti, empati, kasih sayang, perhatian, penghargaan positif dan nasihat. Hadirnya teman sebaya dalam hidup individu akan membantunya dalam mencapai suatu tujuan, sesuai dengan penelitian yang dilakukan oleh Arjanggi dan Suprihatin (2018) yang mengatakan kondisi pembelajaran yang difasilitasi oleh teman sebaya akan akrab akan membuat remaja mengikuti kegiatan pembelajaran, tujuan- tujuan belajar dan target penguasaan materi yang diharapkan. Itulah mengapa teman sebaya mempengaruhi regulasi diri remaja. Dengan memiliki banyak kesamaan dan juga melakukan pengalaman secara bersama-sama membuat peran teman sebaya sangatlah penting bagi remaja. Dengan saling memotivasi satu sama lainnnya membuat mereka bisa melakukan segala sesuatu dengan mudah.

Penelitian tersebut sebagian besar remaja sudah memiliki regulasi diri yang baik. Sebagian besar remaja sudah memiliki tujuan hidup kedepannya bagaimana dan seperti apa. Memiliki penetapan tujuan yang baik dapat membuat remaja mengambil keputusan dengan baik pula dan juga remaja dapat terhindar dari hal-hal yang negatif karena sudah fokus untuk mencapai suatu tujuannya. Seperti pendapat Duckworth, Grant, Loew, Oettingen, dan Gollwitzer (2011) penetapan tujuan dalam diri individu membuat individu memulai sesuatu dan tetap berada di jalur selama tahap pencapaian tujuan. Regulasi diri yang baik pada remaja mampu untuk menekan untuk menekan hal-hal yang negatif seperti pergaulan bebas sampai pemakaian zat- zat berbahaya (narkoba).

Hubungan sosial yang baik akan menimbulkan regulasi yang baik juga. Dengan memiliki regulasi diri yang tinggi membuat remaja memiliki perencanaan, motivasi dan bertindak positif dengan tinggi. Sesuai dengan pendapat manab aspek dalam regulasi diri yaitu; (1) metakognitif, kemampuan individu ketika memikirkan untuk merancang atau merencanakan tindakan (2) motivasi, serangkaian usha yang mungkin berasal dari luar ataupun berasan dari individu (3) tindakan positif, tindakan yang dilakukan individu ketika telah menyeleksi dan menghasilkan perilaku yang dapat diterima oleh lingkungan masyarakat ataupun sesuai dengan tujuan yang diharapkan, semakin besar dan optimal usaha yang dikarahkan individu dalam melakukan suatu aktivitas maka akan meningkatkan regulasi individu.

Sesuai dengan teori sosial kognitif yang dikemukakakan oleh Bandura Teori Sosial Kognitif, mereka memiliki kesamaan dalam penekanan akan pentingnya kepercayaan, persepsi dan observasi perilaku orang lain dalam menentukan apa yang kita pelajari dan bagaimana kita 
bertindak (Wade \& Travis, 2007). Menurut John, Robins, dan Pervin (1999), kognitif dan lingkungan diperlukan sebagai pengaruh untuk menghasilkan perilaku seseorang. Adanya proses interaksi timbal balik antara kognitif, lingkungan dan perilaku. Dukungan dari lingkungan mempengaruhi pemikiran seseorang. Dukungan berupa memberikan saran, informasi dan penghargaan atas apa yang dilakukan akan menjadikan dukungan tersebut menjadi suatu penguat bagi individu untuk melakukan sesuatu atau membuat suatu keputusan dalam hidupnya.

Dukungan tersebut yang membuat remaja melakukan pembelajaran melalui observasi pada lingkungannya, dari observasi yang dilakukan mempengaruhi individu pada kognitifnya. Karena selain lingkungan seseorang, proses kognitif internal maupun karakteristik kepribadian dari individu sangat mempengaruhi. Dukungan yang diterima akan sampai pada kognitiv individu sebagai sumber informasi individu dalam menetapkan tujuannya, setelah itu dengan tujuan yang sudah ditetapkan akan mempengaruhi perilaku individu. Seperti, termotivasi untuk berubah dengan memantau kemajuan yang dilakukannya untuk mencapai suatu tujuan dengan konsisten. Perilaku yang ditunjukkan setelah itu ialah bekerja sesuai dengan rencana yang telah dibuat sebelumnya setelah bekerja sesuai dengan rencananya individu akan melakukan evaluasi pada apa yang sudah dikerjakannya.

Kelebihan dari penelitian ini yaitu melihat faktor eksternal yang dapat mempengaruhi regulasi diri. Selain itu, jumlah responden yang cukup besar diharapkan dapat mewakili usia remaja seluruhnya. Selain kelebihan, kekurangan juga ditemukan pada penelitian ini yaitu sumber penelitian yang relevan apakah penelitian ini bisa didukung atau tidak, dikarenakan sedikit sekali peneliti yang membahas faktor eksternal yang mempengaruhi regulasi diri. Oleh karena itu, peneliti mengharapkan untuk dapat dilakukannya penelitian serupa dengan kajian dan cakupan yang lebih luas lagi.

\section{KESIMPULAN}

Berdasarkan hasil penelitian yang telah dilakukan terdapat pengaruh positif dukungan teman sebaya terhadap regulasi diri pada remaja. Hasil penelitian tersebut menunjukkan bahwa semakin tinggi dukungan teman sebaya maka semakin tinggi pula regulasi diri pada remaja. Begitu juga sebaliknya semakin rendah dukungan teman sebaya, maka semakin rendah pula regulasi diri pada remaja. Maka dapat disimpulkan hipotesis yang dibuat oleh peneliti diterima.

\section{IMPLIKASI}

Implikasi yang dapat diberikan dalam penelitian ini adalah para remaja diharapkan dapat menjaga kualitas hubungannya dengan teman sebaya, memberikan dukungan satu sama lainnya agar mampu meningkatkan motivasi dan pada akhirnya memiliki hubungan timbal balik antar individu. Dengan begitu remaja menerima dukungan-dukungan dari teman sebayanya agar terhindar dari hal-hal yang negatif dan mampu untuk meningkatkan regulasi diri pada remaja. Adapun keterbatasan pada penelitian ini adalah peneliti hanya melakukan penelitian pada remaja SMP dan tidak pada remaja SMA.

\section{DAFTAR PUSTAKA}

Almasitoh, U. H. (2011). Stres kerja ditinjau dari konflik peran ganda dan dukungan sosial pada perawat. Jurnal Psikologi Islam, 8(1), 63-82. Retrieved from http://id.wikipedia.org/wiki/perawat

Arjanggi, R., \& Suprihatin, T. (2018). Metode pembelajaran tutor teman sebaya meningkatkan hasil belajar berdasar regulasi-diri. Makara Human Behavior Studies in Asia, 14(2), 91. 
https://doi.org/10.7454/mssh.v14i2.66 6

Aziroh, L. F. (2017). Pengaruh regulasi diri dan motivasi berprestasi terhadap perilaku menyontek siswa siswa MTS Muftahul Huda Bulungan Pakis Aji Jepara. Skripsi, Universitas Islam Negeri Walisongo. https://doi.org/http://eprints.walisongo. ac.id/8231/

Bandy, T., \& Moore, K. A. (2010). Assessing self-regulation: a guide for out-of-school time program practitioners. Retrieved from https://www.childtrends.org/publicatio ns/assessing-self-regulation-a-guidefor-out-of- school-time-programpractitioners.

Dennis, C.-L. (2003). The effect of peer support on postpartum depression: a pilot randomized controlled trial. In Can J Psychiatry 48(2), 115-124

Duckworth, A. L., Grant, H., Loew, B., Oettingen, G., \& Gollwitzer, P. M. (2011). Self- regulation strategies improve self-discipline in adolescents: Benefits of mental contrasting and implementation intentions. Educational Psychology, 31(1), 17-26. https://doi.org/10.1080/01443410.2010 .506003

Elleny. (2007). Dukungan sosial dan harga diri pada pembantu rumah tangga di Yogyakarta.

Istriyanti, N. L. A., \& Simarmata, N. (2014). Hubungan antara regulasi diri dan perencanaan karor pada remaja putri Bali. Jurnal PSikologi Udayana, 1(2), 301-310.
John, O. P., Robins, R. W., \& Pervin, L. A. (1999). Theory and Research. In Handbook of Personality.

Leme, V. B. R., Del Prette, Z. A. P., \& Coimbra, S. (2015). Social skills, social support and well-being in adolescents of different family configurations. Paideia, 25(60), 9-17. https://doi.org/10.1590/198243272560201503

Lutfi, D. N. (2012). Hubungan antara dukungan teman sebaya dengan kemampuan pemecahan masalah pada santriwati pengurus organisasi pelajar PPMI Assalam (OP3MIA). Skripsi, Universitas Muhammadiyah Surakarta.

Manab, A. (2016). Memahami regulasi diri: sebuah tinjauan konseptual. Retrieved from http://mpsi.umm.ac.id/files/file/711 Abdul Manab.pdf

Nelson, R. M., \& Debacker, T. K. (2008). Achievement motivation in adolescents: The role of peer climate and best friends. Journal of Experimental Education, 76(2), 170189.

https://doi.org/10.3200/JEXE.76.2.170 $-190$

Nisfiannoor, M., \& Kartika, Y. (2004). Hubungan antara regulasi emosi dan penerimaan kelompok teman sebaya pada remaja. Jurnal Psikologi, 2(2), 160-178.

Nuperawati, T., Yufiarti, \& Sumantri, M. S. (2018). Hubungan antara persepsi siswa tentang pola asuh orang tua dan regulasi diri dengan keterampilan sosial. Jurnal Pendidikan Anak Usia Dini, 2(1), 2580-4197.

Oppenheimer, C. W., \& Hankin, B. L. (2011). Relationship quality and 
depressive symptoms among adolescents: A short-term multiwave investigation of longitudinal, reciprocal associations. Journal of Clinical Child and Adolescent Psychology, 40(3), 486-493.

https://doi.org/10.1080/15374416.2011 .563462

Ormrod, J. E. (2008). Psikologi pendidikan : membantu siswa tumbuh dan berkembang. Jakarta: Penerbit Erlangga

Pardede, E. N., Supena, A., \& Fahrurrozi. (2018). hubungan kelekatan orangtua dan regulasi diri dengan kemampuan sosial anak (Studi korelasi pada anak kelas 3 di SD Pangudi Luhur Jakarta, 2017). Jurnal Pendidikan Usia Dini, 12(1), 2503-0566.

Pichardo, C., Justicia, F., De La Fuente, J., Martínez-Vicente, J. M., \& Berbén, A. B. G. (2014). Factor structure of the Self-Regulation Questionnaire (SRQ) at Spanish universities. Spanish Journal of Psychology, 17(e62), 1-8. https://doi.org/10.1017/sjp.2014.63

Rasyid, M. (2012). Hubungan antara Peer Attachment dengan Regulasi Emosi Remaja yang Menjadi Siswa di Boarding School SMA Negeri 10 Samarinda. In Jurnal Psikologi Pendidikan dan Perkembangan 1(03), 01-07

Ristianti, A. (2008). Hubungan Antara Dukungan Sosial Teman Sebaya dengan Identitas Diri Pada Remaja di SMA Pusaka 1 Jakarta. Retrieved from https://www.academia.edu/22547967/ Hubungan Antara Dukungan Sosial Teman_Sebaya dengan_Identitas_Diri _Pada_Remaja_di_SMA_Pusaka_1_Ja karta
Sali, G., \& Akyol, A. K. (2010). A study on the peer relationships, social support perceptions and perfectionism of working and non-working children. Procedia - Social and Behavioral Sciences, 9, 968-974. https://doi.org/10.1016/j.sbspro.2010.1 2.269

Santrock, J. W. (2012). Perkembangan masa hidup. Jakarta: Penerbit Erlangga

Saputri, M. A. W., \& Indrawati, E. S. (2011). Hubungan antara dukungan sosial dengan depresi pada lanjut usia yang tinggal di Panti Wreda Wening Wardoyo Jawa Tengah. Jurnal Psikologi Undip, 9(1), 65-72.

Smith, S. M., Paul, G., Kelly, A., Whitford, D. L., O'Shea, E., \& O'Dowd, T. (2011). Peer support for patients with type 2 diabetes: Cluster randomised controlled trial. BMJ, 342(7795), 482. https://doi.org/10.1136/bmj.d715

Sugiyono. (2017). Metode penelitian kuantitatif, kualitatif, dan R\&D. Bandung: Afabeta, CV

Taa, S., \& Sawitri, D. R. (2017). Hubungan antara dukungan teman sebaya dengan efikasi diri akademik pada siswa sma dan smk beretnis papua di kota Semarang. In Jurnal Empati, 7(3), 212216.

Ulfah, A. N., \& Ariati, J. (2017a). Hubungan dukungan teman sebaya dengan motivasi berprestasi pada santri Pesantren Islam Al-Irsyad, Kecamatan Tengaran, Kabupaten Semarang. In Jurnal Empati, 6(4), 297-301.

Vago, D. R., \& Silbersweig, D. A. (2012). Self-awareness, self-regulation, and self- transcendence (S-ART): a framework for understanding the 
neurobiological mechanisms of mindfulness. Frontiers in Human Neuroscience, 6(296), 1-30. https://doi.org/10.3389/fnhum.2012.00 296.

Wade, C., \& Travis, C. (2007). Psikologi, edisi ke-9. Jakarta: Penerbit Erlangga.

Walen, H. R., \& Lachman, M. E. (2000). Social support and strain from partner, family, and friends: Costs and benefits for men and women in adulthood. In Journal of Social \& Personal Relationships 17(1), 6-30. Retrieved from http://midmac.med.harvard.edu.

Wills, Thomas A., \& Bantum, E. O. (2012). Social Support, Self-Regulation, and Resilience in Two Populations: General-Population Adolescents and Adult Cancer Survivors. Journal of Social and Clinical Psychology, 31(6), 568-592.

https://doi.org/10.1521/jscp.2012.31.6. 568.

Wills, Thomas Ashby, Resko, J. A., Ainette, M. G., \& Mendoza, D. (2004). Role of parent support and peer support in adolescent substance use: A test of mediated effects. Psychology of Addictive Behaviors, 18(2), 122-134. https://doi.org/10.1037/0893-

164X.18.2.122.

Yayan, M., Yuniarrahmah, E., \& Anward, H. H. (2016). Gambaran regulasi diri dan perilaku kenakalan seksual pada remaja di Batulicin. Jurnal Ecopsy, 3(2), 82-87. Retrieved from http://health.detik.com/.

Zimmerman, B. J. (2000). Attaining selfregulation: A social cognitive perspective. In Handbook of SelfRegulation (pp. 13-39). 